Journal of Mechanical Engineering and Sciences

ISSN (Print): 2289-4659; e-ISSN: 2231-8380

Volume 12, Issue 4, pp. 4044-4055, December 2018

(C) Universiti Malaysia Pahang, Malaysia

DOI: https://doi.org/10.15282/jmes.12.4.2018.05.0351

\title{
Effect of inlet air temperature on SI engine fueled with diethyl ether-gasoline blends
}

\author{
Sanjay Kumar. $\mathbf{D}^{1}$, Srihari. $\mathbf{S}^{1}$ and Thirumalini.. ${ }^{1}$ \\ ${ }^{1}$ Department of Mechanical Engineering, \\ Amrita School of Engineering, \\ Coimbatore Campus, Amrita Vishwa Vidyapeetham, India. \\ Phone: +919942528512 \\ *Email: s_srihari@cb.amrita.edu
}

\begin{abstract}
In this study the performance and emission characteristics of spark ignition genset engine fueled with gasoline and diethyl ether (DEE) blends are carried out. The DEE blends are varied from $3 \%, 6 \%$ and $9 \%$ by volume in gasoline. A four-stroke single cylinder constant speed spark ignition engine is used for the experiments. The variation in fuel consumption and exhaust emission with respect to two different inlet air temperatures are studied. The concentration of exhaust emissions such as $\mathrm{HC}, \mathrm{CO}, \mathrm{NO}_{\mathrm{x}}$ is observed. The parameters such as inlet air temperature, brake specific fuel consumption, relative air to fuel ratio are also measured. It is noticed that $6 \%$ DEE blend in gasoline reduced almost reduced HC emission about $57 \%$ and also considerable reduction in $\mathrm{CO}$ emission at lower air intake temperature. The addition of diethyl ether has an improvement in performance and significant reduction in $\mathrm{HC}, \mathrm{CO}$ and $\mathrm{NO}_{\mathrm{x}}$ emissions.
\end{abstract}

Keywords: Fuel; diethyl ether; emissions; temperature; additives.

\section{INTRODUCTION}

The domestic and commercial power requirement is on the increase day by day. The normal grid power supply is insufficient and unreliable. The genset plays a major role in overcoming this issue catering to low power domestic applications [1]. A genset is a combination of an alternator and a prime mover. The prime mover can be a petrol engine or diesel engine. The petrol genset is often used for lower power applications where as diesel genset is mainly used for high power requirements [2]. One area where gasoline genset scores over diesel genset is during the cold weather starts. The heat necessary for combustion is achieved by a spark plug in gasoline genset hence cold start issues can be avoided [3]. The inlet air temperature plays a major role in combustion of fuel as well in exhaust emissions [4]. In order to study the variations with temperature change, the average temperature in summer and winter seasons in central and southern part of India are taken into account for this study. So the tests are conducted at $32^{\circ} \mathrm{C}$ for summer and $22^{\circ} \mathrm{C}$ for winter seasons.

The increase in price of gasoline and increase in environmental pollution due to internal combustion engines have forced the engineers all over the world to work on alternate fuels and fuel additives for improvement in efficiency with reduction in emissions. The exhaust emissions such as hydrocarbon (HC), carbon monoxide (CO), 
oxides of nitrogen $\left(\mathrm{NO}_{\mathrm{x}}\right)$ undergo series of reactions in the atmosphere and which are hazardous to health [5]. They lead to global warming, acid rain and respiratory track problems. The ultimate aim is to develop a fuel which reduces harmful exhaust emissions [6]. The organic compounds which contain oxygen are known as oxygenates. It could be alcohols, ethers, esters, ketones and carbonates.

Jaat et al [7] experimentally established a reduction in ignition delay with increase in ambient temperature of biodiesel blends and its oxygen content did play a significant role. It was established that leaning effect in oxygenated blends such as with ethanol decreases $\mathrm{CO}$ and $\mathrm{HC}$ emissions in gasoline engines [8,9]. The organic compounds which contain oxygen are known as oxygenates. It could be alcohols, ethers, esters, ketones and carbonates [10]. Oxygenates are used as substitutes for lead additives in gasoline to enhance octane rating [11]. The amount of oxygenates added to gasoline can vary from $3 \%$ to $22 \%$ by volume. There is a decrease in energy content of the blended fuel and increase in fuel consumption depending on the amount and type of oxygenates added to the gasoline. This resulted in change of the air to fuel ratio and ensures complete combustion of fuel into $\mathrm{CO}_{2}$ and $\mathrm{H}_{2} \mathrm{O}[12,13]$. Ethanol addition to unleaded gasoline increase the engine torque, power and fuel consumption and reduce $\mathrm{CO}, \mathrm{NO}_{\mathrm{x}}$ and $\mathrm{HC}$ emissions. It was also found that ethanol-gasoline blends allow increase of compression ratio (CR) without the occurrence of knock [14]. It was observed that gasoline with a $35 \%$ butanol blend and ignition optimization, torque, power, brake specific fuel consumption (BSFC), $\mathrm{HC}, \mathrm{CO}$ and $\mathrm{O}_{2}$ emissions reduced and $\mathrm{NO}_{\mathrm{x}}$ and $\mathrm{CO}_{2}$ emissions indicated an increase [15]. It was also reported that with small percentage of hydrogenethanol blends, the power produced by a SI engine was substantially higher [16]. Addition of methane in gasoline, acceleration in combustion was observed at low compression ratio with lean burning and fuel stratification conditions. A slight increase in in-cylinder pressure was observed leading to improvement in initial combustion $[17,18]$.

It is seen that alcohols and ethers are the commonly used additives. Alcohols has drawbacks such as high volatility, solubility in water, phase separation problem, high Reid vapor pressure which can cause clogging of the blended fuel due to increase in vapor pressure. It has high latent heat of vaporization which leads to cold start up and drivability issues. On the other hand, ethers are capable to overcome all the drawbacks and enhance gasoline combustion with high octane numbers and reduced $\mathrm{HC}, \mathrm{CO}$, and $\mathrm{NO}_{\mathrm{x}}$ emissions [19]. Being toxic the usage of organic compounds with methyl group are shown less interest in many countries such as USA, GBR, France, etc. Since diethyl ether (DEE) is non-toxic and readily available with affordable cost is used as additive [20]. The DEE is synthesized by the reaction of ethanol with sulphuric acid in an aqueous medium at a temperature below $150^{\circ} \mathrm{C}$ through dehydration process. It is an excellent CI engine fuel with high energy density than ethanol and aids cold start for engines [21]. The use of DEE blends under various load conditions in a CI engine. It was found that specific fuel consumption reduced at full load and injection timing needs to be advanced for reduction in smoke and HC emissions [22]. Studies on addition of DEE with LPG and CI in HCCI combustion mode indicate a reduction in thermal efficiency along with a reduction in $\mathrm{NO}_{\mathrm{x}}$ and soot. However, an increase in $\mathrm{CO}$ and $\mathrm{HC}$ was observed with addition of $15 \%$ diethyl ether in diesel, injection timing was varied to find an optimized one. At full load conditions, advancement in injection timing reduced smoke and $\mathrm{HC}$ emissions and retardation improved the brake thermal efficiency and $\mathrm{NO}_{\mathrm{x}}$ [23]. It was observed that the effect of variation in inlet air temperature on engine performance and emission characteristics on petrol engine is not yet discussed. In pursuit of a renewable high cetane number fuel comparable to conventional fuels for engines DEE was chosen. DEE is a 
liquid fuel at ambient temperature and can be used as a fuel additive in engines without modifications. There are some concerns on the impact of DEE on air pollution during storage due to its high volatility and its tendency to oxidize and form peroxide [24]. Limited research has been observed on DEE-gasoline blends in spark ignition engines. In this study the effect on performance and emission characteristics of the gasoline and gasoline-DEE blends are used in gasoline engine. The effect on inlet air temperature at $22^{\circ} \mathrm{C}$ and $32^{\circ} \mathrm{C}$ are also analyzed and presented.

\section{METHODS AND MATERIALS}

The experiments are conducted on an air cooled, single cylinder, 4-stroke, gasoline constant speed engine. The engine is coupled with transient dynamometer. A load cell is attached with the dynamometer is used to measure load acting on the engine. The load cell has the rage of $0-100 \mathrm{Nm}$ and has accuracy of $0.1 \mathrm{Nm}$ with the error of $\pm 0.87 \mathrm{Nm}$ to its full scale. The schematic layout of the experimental set up is shown in Figure 1. The specification of the engine is detailed in Table 1. The fuel blends used in the experiment and its properties are presented in Table 2. Fuel properties such as density, viscosity, and calorific values are measured by using hydrometer, redwood viscometer and bomb calorimeter respectively. The latent heat of vaporization and auto ignition temperature are calculated based on the mass fraction used in the gasoline and is presented.

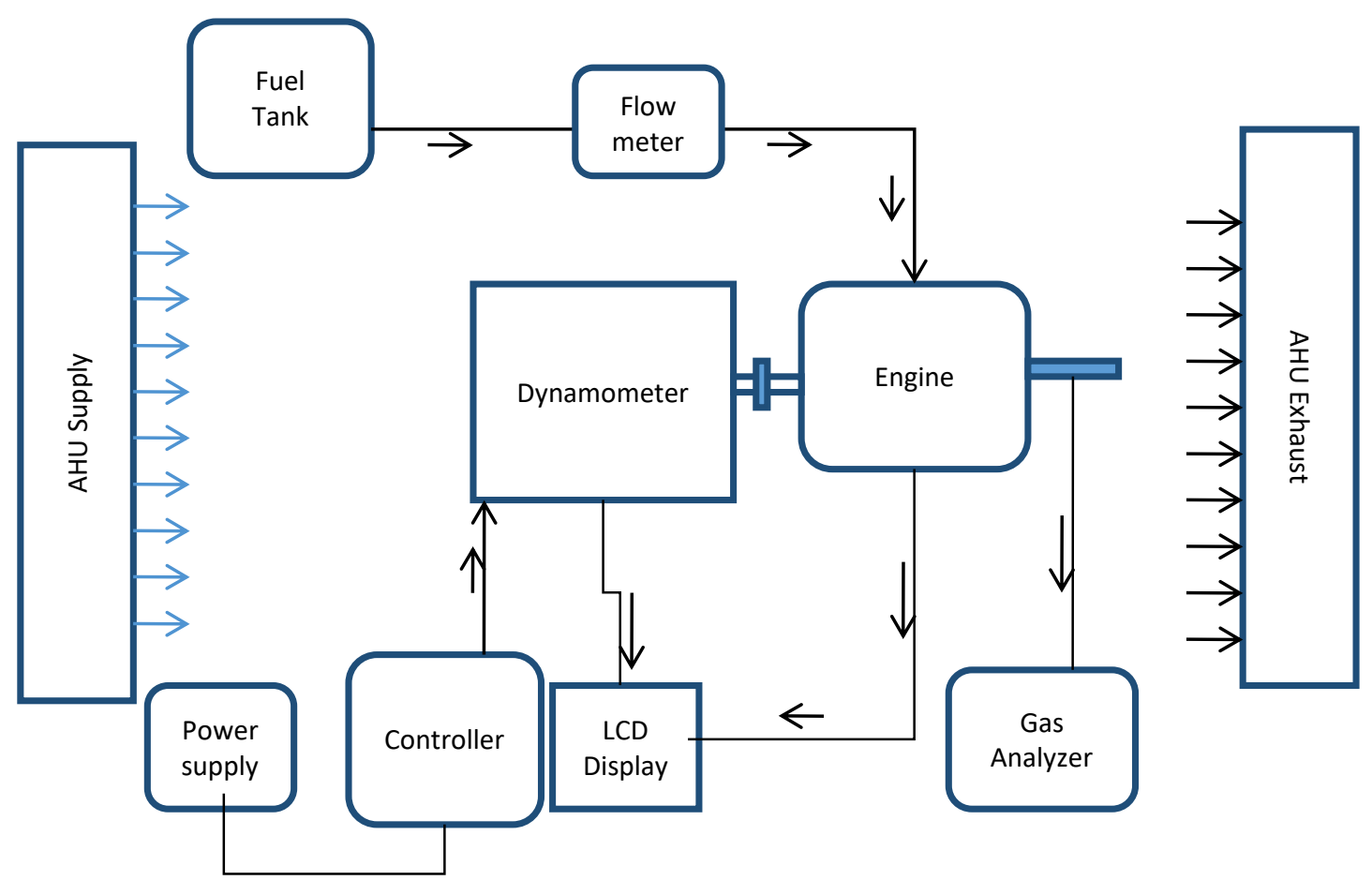

Figure 1. Schematic layout of the experimental setup.

The column tube manometer is used for measuring the fuel consumed by the engine. The inlet and exhaust gas temperatures are measured by using the thermocouples fixed at inlet and exhaust manifold respectively. The Horiba Mexa 584L gas analyzer is used to measure the concentrations of exhaust gas emissions. The specification of the gas 
analyzer is given in Table 3. The required inlet air temperature is maintained constant by air handling unit (AHU) in the test bed as shown in Figure 1.

Table 1. Engine specifications

\begin{tabular}{ll}
\hline Engine type & Single cylinder, 4- stroke, air cooled \\
\hline Engine make & Briggs and Stratton \\
Fuel & Gasoline \\
Bore $(\mathrm{mm})$ & 89 \\
Stroke $(\mathrm{mm})$ & 63 \\
Peak torque $(\mathrm{Nm})$ & 25.9 \\
Rated power $(\mathrm{kW})$ & 9.7 \\
Rated speed $(\mathrm{rpm})$ & 3600 \\
\hline
\end{tabular}

Table 2. Properties of the fuel $[12,13]^{\mathrm{a}}[7,21,28]^{\mathrm{b}}$

\begin{tabular}{|c|c|c|c|c|c|}
\hline Properties & Gasoline $^{\mathrm{a}}$ & $\begin{array}{l}\text { Diethyl } \\
\text { ether }^{\mathrm{b}}\end{array}$ & $\begin{array}{l}97 \% \mathrm{G}+ \\
3 \% \mathrm{DEE}\end{array}$ & $\begin{array}{l}94 \% \mathrm{G}+ \\
6 \% \mathrm{DEE}\end{array}$ & $\begin{array}{l}91 \% \mathrm{G}+ \\
9 \% \mathrm{DEE}\end{array}$ \\
\hline Calorific value $(\mathrm{kJ} / \mathrm{kg})$ & 44500 & 33892 & 44420 & 43865 & 43545 \\
\hline $\begin{array}{l}\text { Latent heat of } \\
\text { vaporization }(\mathrm{kJ} / \mathrm{kg})\end{array}$ & 331.6 & 376 & 332.9 & 334.2 & 335.6 \\
\hline $\begin{array}{l}\text { Kinematic viscosity at } \\
\mathrm{T}=32^{\circ} \mathrm{C}(\mathrm{cSt})\end{array}$ & 0.41 & 0.22 & 0.40 & 0.398 & 0.392 \\
\hline $\begin{array}{l}\text { Kinematic viscosity at } \\
\mathrm{T}=22^{\circ} \mathrm{C}(\mathrm{cSt})\end{array}$ & 0.44 & 0.32 & 0.44 & 0.43 & 0.43 \\
\hline $\begin{array}{l}\text { Density }\left(\mathrm{kg} / \mathrm{m}^{3}\right) \\
\text { ASTM D4052 }\end{array}$ & 719.7 & 713 & 718 & 716 & 715 \\
\hline Flash point $\left({ }^{\circ} \mathrm{C}\right)$ & -43 & -40 & - & - & - \\
\hline $\begin{array}{l}\text { Auto ignition } \\
\text { temperature }\left({ }^{\circ} \mathrm{C}\right)\end{array}$ & 257.2 & 160 & 254 & 251 & 248 \\
\hline Octane number & 91 & 14 & - & - & - \\
\hline
\end{tabular}

A thermocouple is fitted in the AHU exhaust to control the temperature inside the bed. The miscibility of DEE blends with gasoline is ensured properly by stirring the fuel with a magnetic stirrer.

Table 3. Specifications of gas analyzer

\begin{tabular}{llll}
\hline Pollutant & Range & Resolution & Principles \\
\hline $\mathrm{NO}_{\mathrm{x}}$ & $0-5000 \mathrm{ppm}$ & $1 \mathrm{ppm}$ vol & Chemiluminescence \\
$\mathrm{HC}$ & $0-20000 \mathrm{ppm}$ & $1 \mathrm{ppm}$ vol & Non-dispersive infrared \\
$\mathrm{CO}$ & $0-20 \%$ volume & $0.01 \%$ vol & Non-dispersive infrared \\
$\mathrm{CO}_{2}$ & $0-20 \%$ volume & $0.01 \%$ vol & Non-dispersive infrared \\
$\mathrm{O}_{2}$ & $0-25 \%$ volume & $0.01 \%$ vol & Carbon balance method \\
\hline
\end{tabular}

\section{Experimental Procedure}

The engine is tested based on the procedure recommended by Central Pollution Control Board (CPCB) of India for gasoline genset engine. The engine is started and allowed to 
warm up until it attains thermal stability which can be ensured by attaining the constant exhaust gas temperature and surface temperature of cylinder head. The residual fuel in the fuel line is flushed out before each test with the new blend. The experiments are carried out by blending 3\%, 6\% \& 9\% diethyl ether with gasoline at the inlet air temperature of $32^{\circ} \mathrm{C}$ and $22^{\circ} \mathrm{C}$.DEE can increase wear rate in the engines, it restricts the usage in large quantities [25]. Hence the percentage of DEE is used less than $10 \%$ by volume in this study. The data are observed by taking two runs and the average value of the required parameters. According to the CPCB test procedure [26], the engine is subjected run at three modes such as 50\%, 75\%, 100\% of rated load at a constant speed. The speed of the engine is fixed at $3000 \mathrm{rpm}$. The alternator which is coupled to the engine has to produce the alternate current (AC) of $50 \mathrm{~Hz}$ power supply. The speed of the engine is calculated and is fixed based on the frequency required. In order to calculate the speed, the required frequency is multiplied by 120 over number of poles in the generator stator. The maximum torque at $3000 \mathrm{rpm}$ is found by conducting full throttle performance test on the engine and is $25 \mathrm{Nm}$. Table 4 shows the weightage factor, torque and speed for different modes of operation used in the experiment.

Table 4. Details of test modes

\begin{tabular}{llll}
\hline Mode no. & 1 & 2 & 3 \\
\hline Load \% & 100 & 75 & 50 \\
Weightage factor & 0.3 & 0.5 & 0.2 \\
Speed (rpm) & 3000 & 3000 & 3000 \\
Torque (Nm) & 25 & 18.75 & 12.5 \\
\hline
\end{tabular}

Table 5. Uncertainties of measured and calculated parameters

\begin{tabular}{lll}
\hline S. No & Parameter & Uncertainty \% \\
\hline 1. & $\mathrm{CO}$ & \pm 1.7 \\
2. & $\mathrm{HC}$ & \pm 1 \\
3. & $\mathrm{NO}_{\mathrm{x}}$ & \pm 1.2 \\
4. & $\mathrm{BP}$ & $\pm 1.05 \%$ \\
5. & $\mathrm{BSFC}$ & $\pm 1.12 \%$ \\
\hline
\end{tabular}

The engine is loaded from $10 \%$ to $100 \%$ of maximum load. The weightage factor is applied only to $100 \%, 75 \%$ and $50 \%$ load conditions. The inlet air conditions are monitored and maintained at the set temperature. The performance parameters such as Specific fuel consumption and exhaust gas temperature are observed. The emission parameters such as $\mathrm{HC}, \mathrm{CO}$ and $\mathrm{NO}_{\mathrm{x}}$ are observed using gas analyzer at each load conditions. The instruments used in the experiments are calibrated before and after the test and the readings are repeatable within the limit prescribed by CPCB. The errors involved in the experiments are calculated using uncertainty analysis which is widely followed among the researchers. Uncertainties of the measured and calculated parameters are found by using Root-sum-square method and are presented in Table 5. 


\section{RESULTS AND DISCUSSION}

The experiments are conducted at a controlled intake temperature of $32 / 22 \pm 1^{\circ} \mathrm{C}$. The various blend percentages of DEE with gasoline used in the experiment are 3\%, 6\% and $9 \%$ by volume. The performance and emission characteristics are observed and presented. The parameters analyzed in the engine are $\mathrm{CO}, \mathrm{HC}, \mathrm{NO}_{\mathrm{x}}$ and $\mathrm{BSFC}$. Figure 2(a) shows the variations of the $\mathrm{CO}$ emissions at inlet air temperature of $32^{\circ} \mathrm{C}$ with respect to load. The CO emission of base fuel and 9\% DEE blends are gradually decreased when the load is increased from $10 \%$ to $50 \%$. Further, the increase in CO is observed at maximum load condition. This is due to decrease in combustion temperature which leads to partial oxidation of $\mathrm{CO}$ to $\mathrm{CO}_{2}$ conversion process [27, 29]. It is observed that when the load increased from $10 \%$ to $75 \%$ the CO emissions are decreased for 3\% DEE and 6\% DEE blends respectively. At maximum load it is seen that the $\mathrm{CO}$ emissions are increased. This could be due to lack of oxygen for complete combustion. The density of the air is decreased due to increase in inlet temperature which reduced the oxygen for combustion [30].

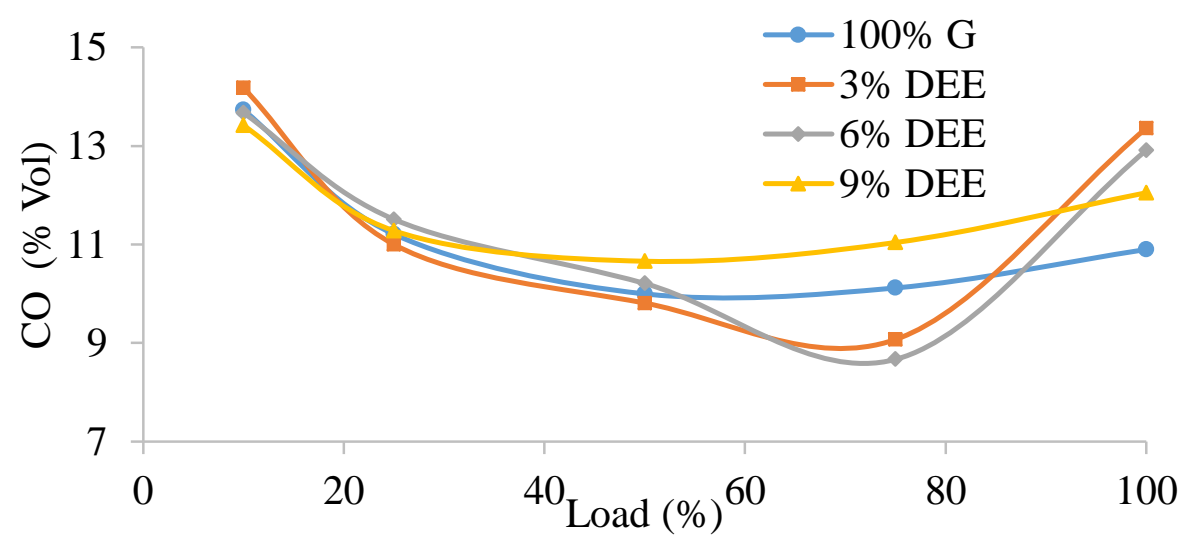

(a)

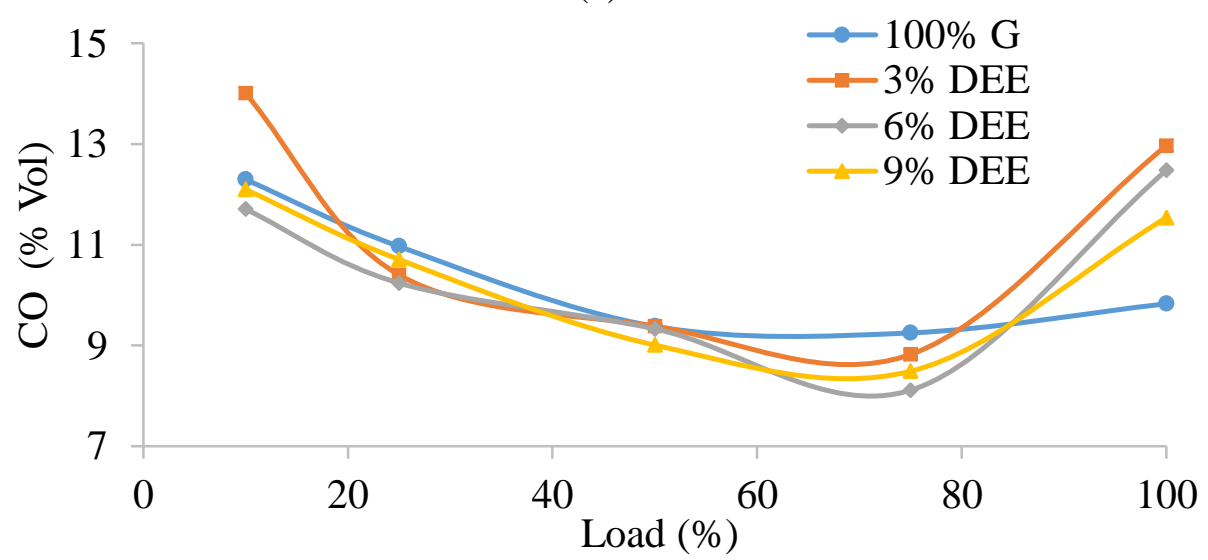

(b)

Figure 2. Comparison of $\mathrm{CO}$ emission with load at (a) $32^{\circ} \mathrm{C}$ inlet air temperature (b) $22^{\circ} \mathrm{C}$ inlet air temperature.

Figure 2(b) shows the variations of the $\mathrm{CO}$ emissions at inlet air temperature of $22^{\circ} \mathrm{C}$ with the load. The $\mathrm{CO}$ emissions of base fuel and 3\%, 6\% and 9\% DEE blends are gradually decreased respectively when the load is increased from $10 \%$ to $75 \%$. It is due to increase in density of air which provided more oxygen for complete combustion of 
fuel. The $\mathrm{CO}$ emission is increased about $33 \%$ at maximum load condition for $3 \%$ DEE blend. This could be due to fuel rich mixture conditions which alters the combustion characteristics and increased $\mathrm{CO}$ emission. As the blend percentage increased, the $\mathrm{CO}$ emission is decreased which could be due to fuel bound oxygen supports for combustion process $[13,31]$. The average $\mathrm{CO}$ emissions are calculated using weightage factor at $3 \%$, $6 \%$ and $9 \%$ DEE blend has the reduction of about $10 \%, 10.5 \%$ and $0.05 \%$ respectively at the inlet air temperature of $32^{\circ} \mathrm{C}$. This could be due to fuel bound oxygen supports for combustion and oxidation of $\mathrm{CO}$. It is observed that $\mathrm{CO}$ emission for 3\%, 6\% and 9\% DEE blends are increased by $6.5 \%, 0.02 \%$ and $0.05 \%$ respectively at $22^{\circ} \mathrm{C}$. The decrease in temperature at the inlet reduces the combustion gas temperature and increases the $\mathrm{CO}$ emission [8].

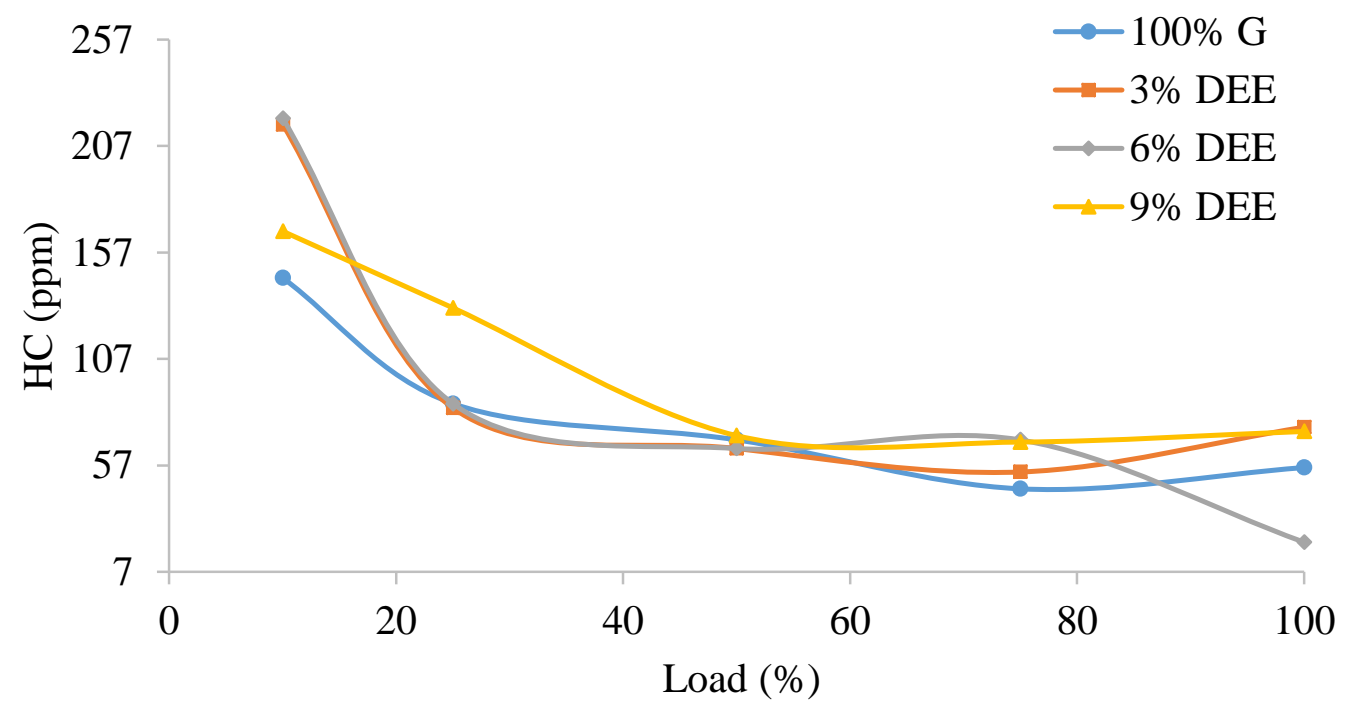

(a)

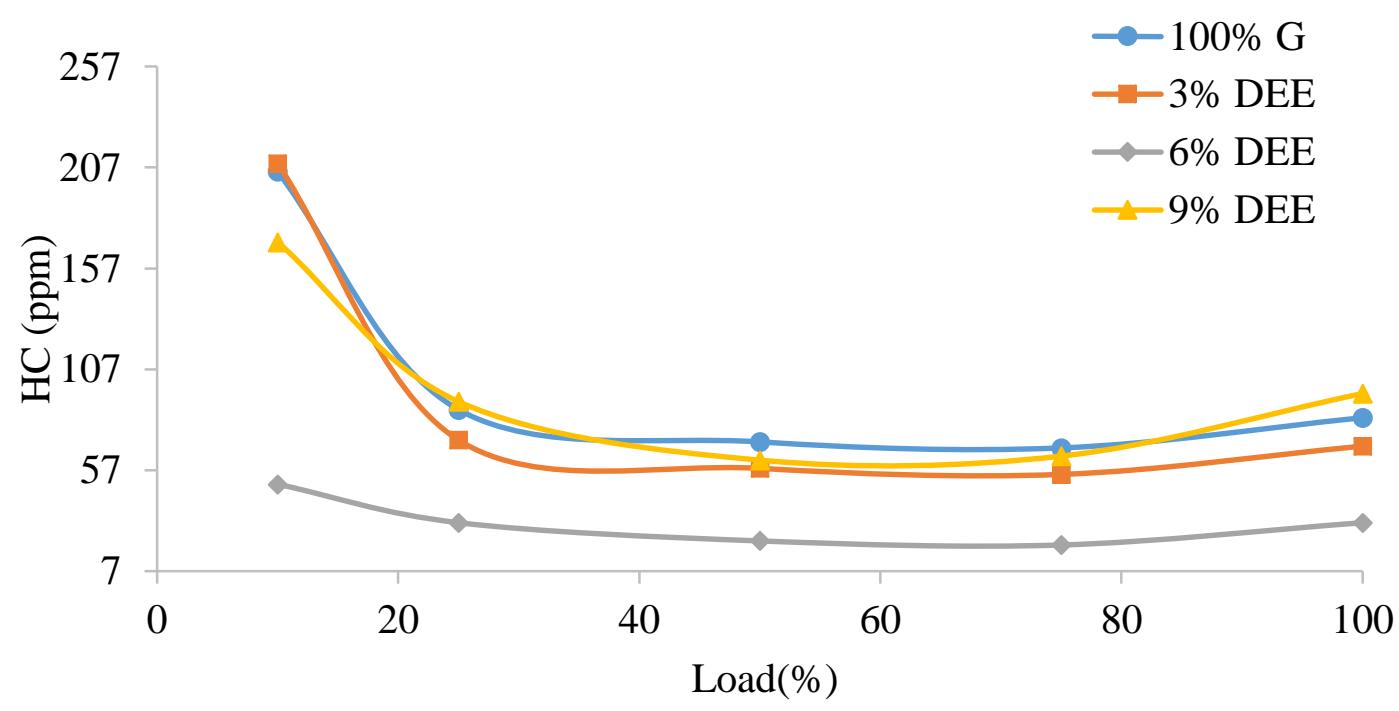

(b)

Figure 3. Comparison of $\mathrm{HC}$ emission with load at (a) $32^{\circ} \mathrm{C}$ inlet air temperature (b) $22^{\circ} \mathrm{C}$ inlet air temperature.

Figure 3(a) shows the variations of the $\mathrm{HC}$ emissions at inlet air temperature of $32^{\circ} \mathrm{C}$ with the load. The HC emissions of the base fuel and 3\%, 6\% and 9\% DEE blends are gradually decreased when the load is increased from $10 \%$ to $75 \%$. At maximum load 
condition, the $\mathrm{HC}$ emissions are increased except for $6 \% \mathrm{DEE}$ blends. It could be due to flame quenching and crevice volume effects significantly contributed to hydrocarbon emission $[32,34]$. It is observed that $6 \%$ DEE blend shows decrease in HC emission at maximum load. It could be because of the addition of DEE reduced the ignition delay [12] and enhanced the combustion characteristics. Figure 3(b) shows the variations of HC emissions at inlet air temperature of $22^{\circ} \mathrm{C}$ with the load. It is found that $6 \% \mathrm{DEE}$ blend shows the reduction in $\mathrm{HC}$ emission in all load conditions. A reduction in $\mathrm{HC}$ emission of about $62 \%$ is observed at maximum load condition. This could be due to better oxidation as the temperature of the inlet air reduced and the oxygen present in the fuel supports for combustion [33]. At maximum load condition, more $\mathrm{HC}$ molecules are trapped in the crevices which significantly contribute to $\mathrm{HC}$ emissions for $9 \%$ DEE blend. It is observed that $\mathrm{HC}$ for 3\%, 6\% and 9\% DEE blends are increased by $9 \%, 0.02 \%$ and $18.3 \%$ respectively. HC emission for 3\%, 6\% and 9\% DEE blends are decreased by $9 \%$, $57 \%$ and $0.1 \%$ respectively at $22^{\circ} \mathrm{C}$. A maximum decrease in $\mathrm{HC}$ emission is observed for $6 \%$ DEE blend.

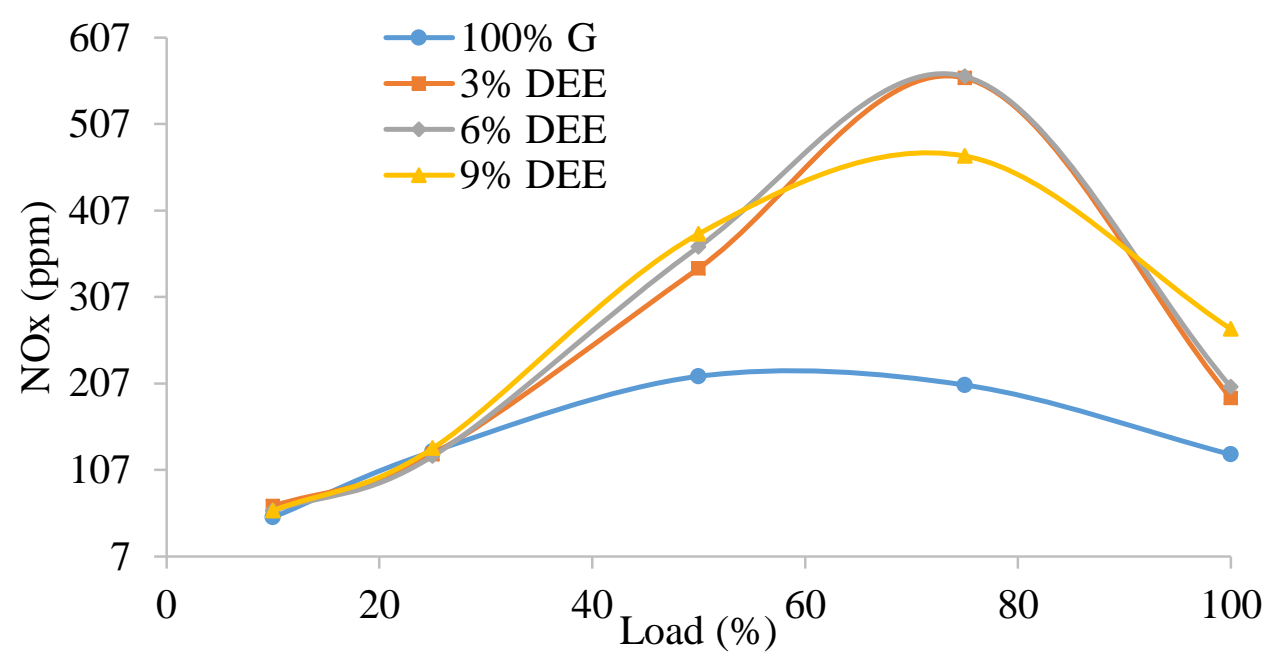

(a)

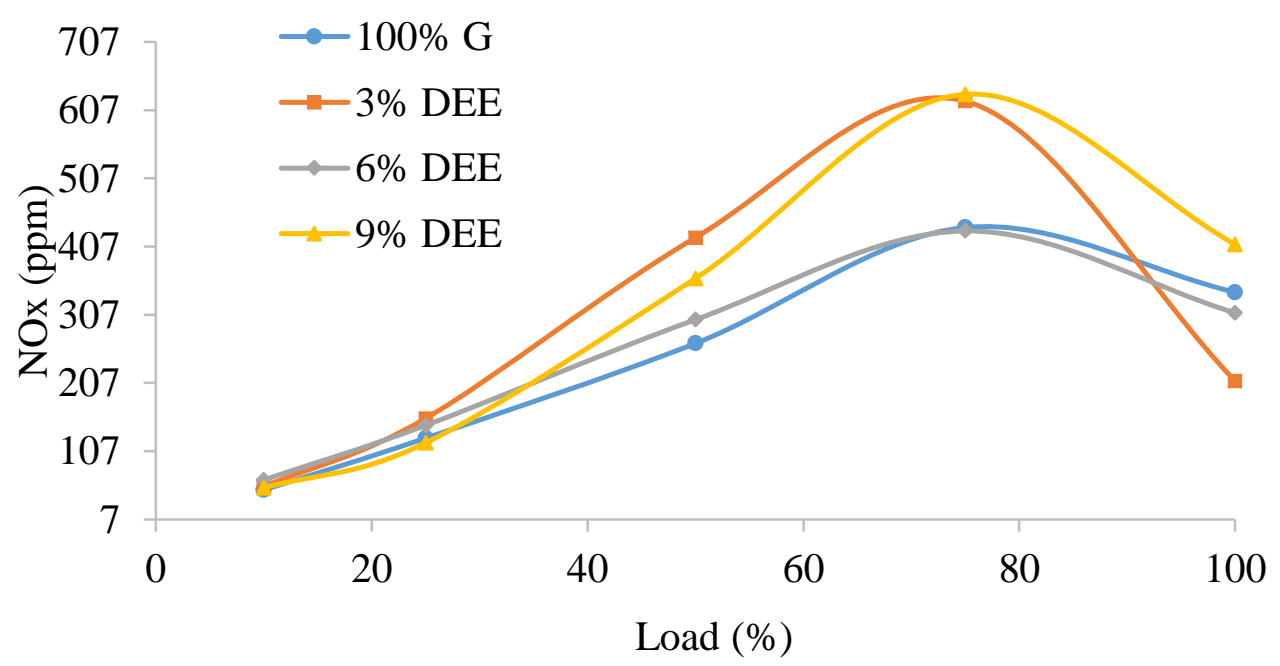

(b)

Figure 4. Comparison of $\mathrm{NO}_{\mathrm{x}}$ emission with load at (a) $32^{\circ} \mathrm{C}$ inlet air temperature (b) $22^{\circ} \mathrm{C}$ inlet air temperature. 
The $\mathrm{NO}_{\mathrm{x}}$ emissions at inlet air temperature of $32^{\circ} \mathrm{C}$ of base gasoline and $\mathrm{DEE}$ blends with different load conditions is shown in Figure 4(a). The air fuel mixture is nearly stoichiometric which enables complete combustion and higher heat release which resulted in higher combustion temperature leads to higher $\mathrm{NO}_{\mathrm{x}}$ emission. At $100 \%$ load condition the $\mathrm{NO}_{\mathrm{x}}$ emission is decreased due to fuel rich conditions resulted in incomplete combustion which reduces the combustion temperature $[11,35]$ and thereby $\mathrm{NO}_{\mathrm{x}}$. Figure 4(b) shows the variation of the $\mathrm{NO}_{\mathrm{x}}$ emissions at inlet air temperature of $22^{\circ} \mathrm{C}$ at different load conditions. The $\mathrm{NO}_{\mathrm{x}}$ emission of base fuel and 3\%, 6\% and 9\% DEE blends are increasing when the load is increased from $10 \%$ to $75 \%$. A reduction in $\mathrm{NO}_{\mathrm{x}}$ about $38 \%$ and $8 \%$ at maximum load condition is observed for $3 \%$ and $6 \%$ DEE blends respectively. This is due to the decrease in air inlet temperature leads to reduction in combustion gas temperature [7] thereby $\mathrm{NO}_{\mathrm{x}}$ emission. It is observed that an average increase in $\mathrm{NO}_{\mathrm{x}}$ of about $112 \%, 116 \%$ and $101.2 \%$ for $3 \%, 6 \%, 9 \%$ DEE blends respectively at $32^{\circ} \mathrm{C}$. It is observed that $\mathrm{NO}_{\mathrm{x}}$ of $3 \%$ and $9 \%$ DEE blend is increased about $28 \%$ and $37 \%$ respectively at $22^{\circ} \mathrm{C}$. The $\mathrm{NO}_{\mathrm{x}}$ is decreased about $1.2 \%$ for $6 \%$ DEE blend $6 \%$ at the same inlet temperature.

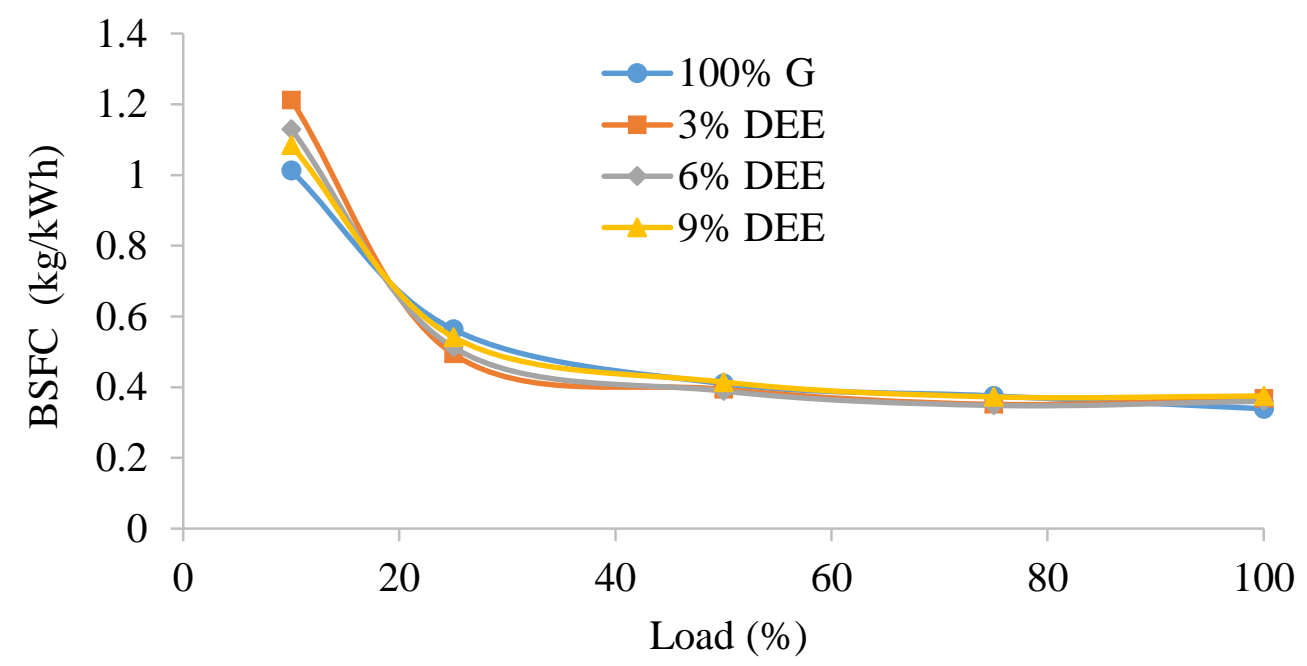

(a)

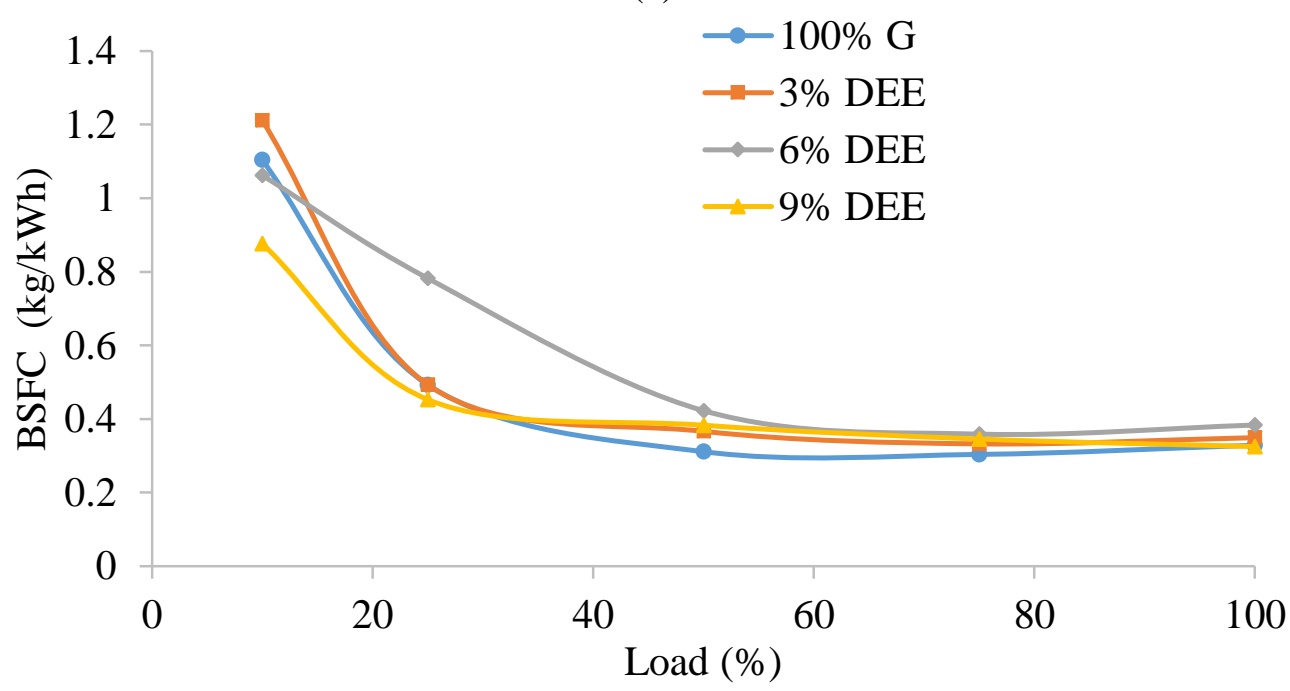

(b)

Figure 5. Comparison of BSFC with load at (a) $32^{\circ} \mathrm{C}$ inlet air temperature (b) $22^{\circ} \mathrm{C}$ inlet air temperature. 
Figure 5(a) and Figure 5(b) shows the variations of BSFC at inlet air temperature of $32^{\circ} \mathrm{C}$ and $22^{\circ} \mathrm{C}$ respectively. The BSFC of base fuel, 3\%, $6 \%$ and $9 \%$ DEE blends are decreased when the load is increased from no load to maximum load conditions. The $\mathrm{BSFC}$ is at par with the base fuel at medium and maximum load conditions at $32^{\circ} \mathrm{C}$. An increase in BSFC of $16 \%$ and $8.5 \%$ is observed for $6 \%$ and $3 \%$ DEE blends at maximum load condition respectively at $22^{\circ} \mathrm{C}$. This is mainly due to decrease in calorific value of the fuel blends as the DEE blend percentage increased [36,21]. It is observed that the $\mathrm{BSFC}$ of $3 \%$ and $6 \%$ DEE blend is decreased to $1.9 \%$ and $3 \%$ respectively at $32^{\circ} \mathrm{C}$. The BSFC is increased about $3 \%$ for $9 \%$ DEE blend. It is observed that the BSFC of $3 \%, 6 \%$, $9 \%$ DEE blend is increased to $11 \%, 19 \%$ and $10.7 \%$ respectively at $22^{\circ} \mathrm{C}$ air inlet temperature.

\section{CONCLUSION}

In this study, three blends of gasoline-DEE were used in a SI engine and the performance and emission characteristics with two inlet air temperature representing the summer and winter average temperatures at the southern part of India was carried out. It was found that the $\mathrm{CO}$ emissions and brake specific fuel consumption reduced for the inlet temperature of $32^{\circ} \mathrm{C}$ and increase in $\mathrm{HC}$ and $\mathrm{NO}_{\mathrm{x}}$ emission was observed. The result for $22^{\circ} \mathrm{C}$ was just the opposite where $\mathrm{CO}$ and $\mathrm{BSFC}$ increased and $\mathrm{HC}$ and $\mathrm{NO}_{\mathrm{x}}$ indicated a decrease. An optimal blend was observed to be $6 \%$ DEE with gasoline which gave reduced emission with marginal reduction in brake specific fuel consumption. A strong correlation of effect of temperature on the emission and performance behavior with DEE and gasoline blends was observed in this study. There is a scope for further studying the SI engine performance by varying the inlet air temperatures and increasing the quantity of DEE in the blends.

\section{ACKNOWLEDGEMENTS}

The authors would like to be obliged to Amrita Automotive Research and Technology Centre (AARTC)-Coimbatore, India for providing support for this project.

\section{REFERENCES}

[1] Katrasnik T, Medica V, Trenc F. Analysis of the dynamic response of a turbocharged diesel engine driven alternating current generating set. Energy Conversion and Management. 2005;46:2838-2855.

[2] Canakci M. Combustion characteristics of a turbocharged DI compression ignition engine fueled with petroleum diesel fuels and biodiesel. Bioresour Technology. 2007;98:1167-1175.

[3] Hampson NB, Stock AL. Storm related carbon monoxide poisoning: lessons learned from recent epidemics. Journal of Undersea \& Hyperbaric Medical Society. 2006;33:257-263.

[4] Kemal M, Sayin C, Canaki M. The effect of different alcohol fuels on the performance, emission and combustion characteristics of a gasoline engine. Fuel. 2012;155:901-906.

[5] Heywood JB. Internal combustion engine fundamentals: McGraw Hill India; 2011. 
[6] Srihari S, Thriumalini S, Prashanth K. An experimental study on performance and emission characteristics of PCCI engine fueled with diethyl ether bio-diesel blends. Renewable energy. 2017;107:440-447.

[7] Jaat N, Khalid A, Andsaler AR, Sapit A, Razali A, Basharie M. Effects of ambient temperature and injection pressure on biodiesel ignition delay. 2017;11:27232733.

[8] Canakci M, Ozsezen AN, Alptekin E, Eyidogan M. Impact of alcohol-gasoline fuel blends on the exhaust emission of an SI engine. Renewable Energy. 2013;52:111-117.

[9] Sasongko MN, Wijayanti W. Effect of ethanol addition on the performance and exhaust emissions of a spark ignition engine. 2017;11: 2734-2742.

[10] Uguluru A, Oztuna S. A comparative analysis study of alternative energy sources for automobiles. International Journal of Hydrogen energy. 2015;40:1-11.

[11] George B, Lakshmikanthan C. Experimental investigation of diesel engine using gasoline as additive. International Journal of Mechanical Engineering and Robotics Research. 2014: 3:386-391.

[12] Balaji D, Maridurai T, Manivarmaa SN. Combustion analysis of diethyl ether blends in gasoline engine operated with ethanol. International Conference on Electrical, Mechanical and Industrial Engineering. 2016;5:237-240.

[13] Balaji D, Govindarajan P, Venkatesan J. Emission and combustion characteristics of SI engine working under gasoline blended with ethanol oxygenated organic compounds. American Journal of Environmental Sciences. 2010;6:495-499.

[14] Koc M, Sekmen Y, Topgul T, Yucesu HS. The effects of ethanol-unleaded gasoline blends on engine performance and exhaust emissions in a spark-ignition engine. Renewable Energy. 2009;34:2101-2106.

[15] Feng R, Fu J, Yang J, Wang Y, Li Y, Deng B, Liu J, Zhang D. Combustion and emissions study on motorcycle engine fueled with butanol-gasoline blend. Renewable Energy. 2015;81:113-122.

[16] Al-Baghdadi MARS. Effect of compression ratio, equivalence ratio and engine speed on the performance and emission characteristics of a spark ignition engine using hydrogen as a fuel. Renewable Energy. 2004;29:2245-2260.

[17] Pan J, Li N, Wei H, Hua J, Shu G. Experimental investigations on combustion acceleration behavior of methane/gasoline under partial load conditions of SI engines. Applied Thermal Engineering. 2018;139:432-444.

[18] Wu B, Wang L, Shen X, Yan R, Dong P. Comparison of lean burn characteristics of an SI engine fueled with methanol and gasoline under idle condition. Applied Thermal Engineering. 2016;95:264-270.

[19] Arteconi A. Emissions from ethers and organic carbonate fuel additives- a review. Water Air Soil Pollution. 2011; 221:405-423.

[20] Chapman EM, Boehman AL. Pilot ignited premixed combustion of dimethyl ether in a turbo diesel engine. Fuel Process Technology. 2008;89:1262-1272.

[21] Ibrahim A. Investigating the effect of using diethyl ether as a fuel additive on diesel engine performance and combustion. Applied Thermal Engineering. 2016;107:853-862.

[22] Patil KR, Thipse SS. The effect of injection timing on the performance and emission of direct injection CI engine running on diethyl ether-diesel blends. 2016;13:3773-3787. 
[23] Miller Jothi NK, Nagarajan G, Renganarayanan S. Experimental studies on homogeneous charge CI engine fueled with LPG using DEE as an ignition enhancer. Renewable Energy. 2007;32:1581-1593.

[24] Barik D, Murugan S. Effects of diethyl ether (DEE) injection on combustion performance and emission characteristics of karanja methyl ester (KME)-biogas fueled dual fuel diesel engine. Fuel. 2016;164:286-296.

[25] Banapurmath NR, Khandal SV, RanganathaSwamy L, Chandrashekar TK. Alcohol (ethanol and diethyl ethyl ether)-diesel blended fuels for diesel engine applications-a feasible solution. Advances in Automobile Engineering. 2015;117:1-8.

[26] Central Pollution Control Board (CPCB). System and procedure for compliance to emission limits for petrol and kerosene driven generator sets up to $19 \mathrm{~kW}$. Ministry of Environment and Forests. Government of India; 2014. http://http://cpcb.nic.in/guidelines

[27] Paul A, Bose PK, Panua RS, Debroy D. Study of performance and emission characteristics of a single cylinder CI engine using diethyl ether and ethanol blends, Journal of Energy Institute. 2015; 88:1-10.

[28] Karabektas M, Ergen G, Hosoz M. The effects of using diethyl ether as additive on the performance and emissions of a diesel engine fuelled with CNG. Fuel. 2014;115: 855-860.

[29] Babu AR, Amba Prasad Rao G, Hari Prasad T. Direct injection of water mist in an intake manifold spark ignition engine. International Journal of Automotive and Mechanical Engineering. 2015;12:2809-2819.

[30] Nik Rosli A, NafisSyabil S, Mohd A, Mamat I, Aminuddin Z. Effects of air intake pressure to the engine performance, fuel economy and exhaust emissions on a small gasoline engine. Journal of Mechanical Engineering and Sciences. 2014;6:949-958.

[31] Ramasamy D, Aik Soon K, Briggs HWG, Zainal ZA. Variation of airflow pattern through dissimilar valve lift in a spark ignition engine. Journal of the Chinese Institute of Engineers. 2013;36:1083-1096.

[32] Ramasamy D, Goh C, Kadirgama K, Benedict F, Noor M, Najafi G,Carlucci AP. Engine performance, exhaust emission and combustion analysis of a 4-stroke spark ignited engine using dual fuel injection. Fuel. 2017;207:719-728.

[33] Zsiga N, Voser C, Onder C, Guzzella L. Intake manifold boosting of turbocharged spark-ignited engines. Energies. 2013;6:1746-1763.

[34] Rashid AK, Mansor A, Radzi M, Ghopa WAW, Harun Z, Mahmood WMFW. An experimental study of the performance and emissions of spark ignition gasoline engine. International Journal of Automotive and Mechanical Engineering. 2016;13:3540-3554.

[35] Catapano F, Sementa P, Vaglieco BM. Air-fuel mixing and combustion behavior of gasoline-ethanol blends in a GDI wall-guided turbocharged multi-cylinder optical engine. Renewable Energy. 2016;96:319-332.

[36] Patil KR, Thipse SS. Characterisation of the key fuel properties of oxygenated diethyl Ether-Diesel blends. Applied Mechanics and Materials. 2014;612:175180. 